\title{
OECONOMIA
}

COPERNICANA

\section{VOLUME 10 ISSUE 1 MARCH 2019}

\author{
p-ISSN 2083-1277, e-ISSN 2353-1827 \\ www.oeconomia.pl
}

\section{ORIGINAL ARTICLE}

Citation: Bieszk-Stolorz, B., \& Dmytrów, K. (2019). Spatial diversity of effectiveness of forms of professional activisation in Poland in years 2008-2014 by poviats. Oeconomia Copernicana, 10(1), 113-130. doi: 10.24136/oc.2019.006

Contact to corresponding author: beata.bieszk-stolorz@ usz.edu.pl; University of Szczecin, Faculty of Economics and Management, Institute of Econ-ometrics and Statistics, ul. Mickiewicza 64, 71-101 Szczecin, Poland

Received: 15.12.2018; Revised: 29.01.2019; Accepted: 9.02.2019; Published online: 1.03.2019

\author{
Beata Bieszk-Stolorz \\ University of Szczecin, Poland \\ (iD) orcid.org/0000-0001-8086-9037 \\ Krzysztof Dmytrów \\ University of Szczecin, Poland \\ (iD) orcid.org/0000-0001-7657-6063
}

\section{Spatial diversity of effectiveness of forms of professional activisation in Poland in years 2008-2014 by poviats}

\author{
JEL Classification: $C 38$; $J 68$
}

Keywords: registered unemployment; forms of professional activisation; cost and employment effectiveness; cluster analysis; $k$-means method

\begin{abstract}
Research background: Because the active labour market policy requires high resources, it is important to analyse the effectiveness of its instruments. For the unemployment, it is essential to identify the groups of persons threatened by the long-term unemployment, to assess the impact of programmes on exit from unemployment and monitoring the disbursement of funds.

Purpose of the article: The goal of the article was identification of clusters of poviats in Poland with respect to cost and employment effectiveness of basic forms of professional activisation in the years 2008-2014.

Methods: The poviats were clustered by means of the k-means method. Variables were standardised and the number of clusters was determined by means of the v-fold cross-validation.

Findings \& Value added: The analysis did not allow to unambiguously specify areas in Poland with better use of funds allocated in the activisation programmes. The poviats in the middle-east Poland were generally characterized by worse values of effectiveness. However, the unemployment rate in these areas was relatively small. On the contrary, the poviats in the north-east Poland had high unemployment rate and the funds were used effectively. Assessment of effectiveness of
\end{abstract}


forms of professional activisation is very important because the activities of poviat labour offices influence the counteraction to unemployment.

\section{Introduction}

Effectiveness is a measure of efficiency of actions taken. It describes the relation of obtained effects to incurred expenses. It is understood as a measure of the extent to which the set goals are achieved. The effectiveness is a subject of many discussions and analyses, because it is an important tool of measurement of efficiency of management. In the theory of economics, the economic effectiveness is considered in two aspects. The first one refers to endeavour the highest output from a certain amount of expenses. The second one is connected with saving of resources, which means reaching specified output with the lowest possible expenses (costs). On the basis of economic policy, under the slogan of effectiveness of the public sector functioning, there are all activities aimed at assessing the effectiveness of the use of state policy instruments. It is necessary to assess whether it is appropriate to continue using the instrument and to identify more effective solutions (Knapińska \& Małecka-Ziembińska, 2016).

In case of the labour market, it is important to monitor the implemented programmes of support for the unemployed persons. From the social point of view, it is important to employ as many unemployed job-seekers as possible. On the contrary, in the case of institutions financing the active programmes of support, the assessment of disbursement of funds is essential. Therefore, when assessing the effectiveness of the implemented programmes, two coefficients are set: employment and cost effectiveness.

The goal of the article is clustering of poviats with respect to the effectiveness of the use of Labour Fund resources by poviat labour offices in years 2008-2014 on financing the basic forms of professional activisation with use of the k-means method. The first part of the paper contains information about the problem of effectiveness of counteracting the unemployment in the literature. It is followed by a description of research methodology, where the $k$-means method is explained. Empirical results are preceded by presenting the registered unemployment in Poland, which is the background of the analysis. It is followed by discussion of results and conclusions. 


\section{Literature review}

In order to mitigate the effects of unemployment, various tools influencing its duration are used. Labour market analyses indicate that rising the benefits for the unemployment persons and extending its duration has impact on extending the length of time of looking for employment (Moffitt, 1985; Katz \& Meyer, 1990; Hunt, 1995; Card \& Levine, 2000; Hahn et al, 2001; Lalive, 2007). It may lead to the existence of the phenomenon of long-term unemployment. Therefore, various programmes of increasing the professional activeness of persons looking for employment are introduced. Active labour market policy and connected with it high costs lead to the necessity of analysing the effectiveness of its instruments and conducting evaluation studies. In case of unemployment these analyses refer to several aspects. Foremost, they are: identification of groups of persons threatened by the long-term unemployment, assessment of influence of introduced programmes on the exit from unemployment and monitoring the disbursement of funds earmarked for these purposes. These analyses are very often based on the James Heckman's (Nobel Memorial Prize in Economic Sciences laureate) scientific achievements (Heckman et al, 1999).

Considering the different situation in various countries, analyses of effectiveness focus on different aspects of the labour market policy. In the Unites States, the income effects of the active employment programmes are mostly analysed. On the other hand, in the European Union, in order to avoid high costs of long-term unemployment, more stress is put on the employment effects. As previously conducted bodies of research show, evaluation of the active labour market programmes (ALMP) is ambiguous. A Swedish analysis, conducted in the 1990's, shows that ALMPs reduced unemployment, but also reduced regular employment. Also, the ALMPs should be used rather in the local scale than in the scale of the whole economy (Calmfors et al, 2002). Similar research was performed in late 1990's in Switzerland. Its main finding was that wage subsidy for temporary jobs in the regular labour market that would otherwise not be taken up by the unemployed was effective programme. Traditional employment programmes had a negative effect on the labour market and effectiveness of training courses was mixed (Gerfin \& Lechner, 2002). In Germany, ALMPs were the part of the Hartz reforms during the period 2003-2005. The conducted research show that such ALMPs, as wage subsidies and start-up subsidies had significantly positive effect on the labour market. On the contrary, job creation schemes had a disadvantageous impact on the employment perspectives (Jacobi \& Kluve, 2006). 
After Poland's accession to the European Union, the scope of activities connected with the professional activisation of the unemployed persons, directed to the persons being in difficult situation on the labour market (for example to women, young or older persons, long-term unemployed) increased. The access to labour market services and promotion of programmes of lifelong learning have been extended. Also, the system of benefits for the unemployed persons has been modified, and a system of incentives to taking up business activity and creation of new workplaces has been introduced. One of main goals of these changes is increase of motivation for looking for a job. The conducted pieces of research indicate that these activities contribute to increasing theprobability and intensity of taking up jobs by the unemployed (Bieszk-Stolorz, 2017).

The instruments used by the labour offices in Poland influence both sides of the labour market: supply and demand. On-the-job training, apprenticeships and vocational training are supply-side instruments. Intervention works, public works, socially useful works and funds for starting a business activity by the unemployed and for equipping a workplace for a targeted unemployed person, also called subsidised employment, form a group of instruments oriented towards demand (Wiśniewski \& Maksim, 2013). Due to the necessity of accounting for EU funds, evaluation studies are carried out. They allow for assessment of actions taken in the direction of positive social and economic changes and their estimation. The counterfactual impact evaluation is the most commonly used technique (European Commission, 2013; Bieszk-Stolorz \& Markowicz, 2015).

\section{Research methodology}

The employment effectiveness (the re-employment rate) is defined as the ratio of the number of unemployed persons who in a given year after completion or interruption of participation in a given form of activisation, within 3 months were employed for at least 30 days, to the number of persons who completed participation in a given form of activisation this year. It is the rate that allows to specify the chances of finding employment after completion of participation in the programme.

The cost effectiveness (the cost of re-employment) is the ratio of the amount of expenditures incurred in a given year for a given form of activisation by the number of unemployed persons who, this year after the end of participation in a given form of activation, obtained employment within 3 months. By means of the cost effectiveness the cost of leading the unemployed person to employment is assessed. 
The research covered poviats in years 2008-2014. There were two reasons of selection of such period. The first one resulted from a change of the methodology of calculation of employment effectiveness of the basic forms of professional activisation since 2015. Therefore, it was not possible to compare this indicator with the previous years directly. The change of methodology consisted in different definition of completion of participation in activisation and accepting the different definition of employment. In previous years, in case of trainings and internships, the date of completion of participation in activisation was the date of graduation from participation in a given form of support. In case of the unemployed persons benefiting from the public works, intervention works, socially useful works, reimbursement of workstation retrofitting or equipment the date of completion of participation was the date of termination of financing from the Labour Fund resources.

Provisions of the Act of 20 April 2004 on employment promotion and labour market institutions specified the date of completion of activisation as the end of the commitment period. In the case of reimbursement of workstation retrofitting or equipment, it is the period in which the employer is obliged to maintain the workstation created or retrofitted from the Labour Fund resources. The conditions under which an activated person may be considered an employed person have also been changed. It has caused a change in the definition of employment. Before 2015, an employed person was a person who, after completing participation in a specific form of activisation, did not register again in the poviat labour office within 3 months. It could have happened that some persons lost jobs and have not registered again and in calculations they were considered as the employed persons. In order to avoid such situations, now it is required that the unemployed person after participation in activisation worked by at least 30 days in the period of 3 months and on this account (with a few exceptions) social insurance premiums were paid to the Social Insurance Institution.

These changes were particularly important in the case of subsidising of the business activity and reimbursement of workstation retrofitting or equipment. These both forms of activisation are connected with a single payment of funds. At the same time, the duration of these forms is long. The assessment of the employment effects after the three months since the payment of funds, or in the period of compulsory business activity, caused that the employment effectiveness for both these forms was $100 \%$, while the cost effectiveness was equal the mean of the amount of grant or refund.

The second cause of choice of the research period results from the data availability. The cost and employment effectiveness were considered as 
variables in the research. Since 2015 onwards, for the poviats they are only given in total, without a breakdown by individual forms.

The clustering was done by means of the $k$-means method. It the iterative clustering method, based on minimisation of the total sum of intragroup distances counted from the centre of gravity of the groups. The coordinates of the centre of gravity are the arithmetic means of values of variables belonging to a given group. The stages of each clustering method are as follows:

- selection of objects and variables,

- choice of normalisation formulas,

- choice of the distance measure,

- choice of the classification method,

- choice of the number of classes,

- assessment of the classification results,

- interpretation and class profiling.

In the analysed case poviats were the cases and the variables - the cost and employment effectiveness of particular forms of professional activisation. All variables must be normalised. There are many normalisation formulas. They can be divided into three groups: standardisation, feature scaling and quotient inversion. Generally, we can apply these formulas rather arbitrarily. In the research, the standardisation was used:

$$
z_{i j}=\frac{x_{i j}-\bar{x}_{j}}{s_{x_{j}}}
$$

where:

$x_{i j}$ - value of the $j$-th variable in the $i$-th object,

$z_{i j}$ - the value of the normalised $j$-th variable in the $i$-th object,

$\bar{x}_{j}$ - mean value of the $j$-th variable,

$S_{x_{j}}-$ standard deviation of the $j$-th variable.

Because the cost and employment effectiveness was calculated on the level of poviats, they were highly diversified. For example in the year 2008 the cost effectiveness of trainings was in the interval from just over 1,000 PLN (city poviat of Leszno) to over 390 thous. PLN (the Wschowa poviat). For the other forms of effectiveness, the situation was similar. Therefore, when clustering such values, it turned out that very often we obtained clusters containing only one - maximum several outlying poviats and the whole rest created the other cluster. Therefore, for the need of grouping the outlying values were eliminated. The Tukey's fences approach was used (Adil \& 
Irshad, 2015, p. 92). The value of the $j$-th variable is considered as outlying, if:

$$
x_{i j}>Q_{3.4_{j}}+1,5 * I Q R_{j}
$$

where:

$Q_{3.4 j}$ - the third quartile of the $j$-th variable,

$I Q R_{j}$ - interquartile range of the $j$-th variable.

$I Q R=Q_{3.4}-Q_{1.4}\left(Q_{1.4}-\right.$ the first quartile, $Q_{3.4}-$ the third quartile).

If the value of the $j$-th variable is higher than the right-hand side of the equation (2), for the need of clustering we accept the right-hand side of this equation.

The Euclidean distance was used as a measure of distance. The next step was determination of the number of clusters. There are 30 procedures allowing to determine this number objectively (Charrad et. al, 2014, p. 3). In the research, the $v$-fold cross-validation was used with the assumption that if we have the certain number of clusters, further division will not occur if it does not decrease the clustering error by less than $3 \%$.

The stages of the $k$-means method are as follows (Reddy \& Jana, 2012, p. 396):

- The set of objects is initially divided into $k$ clusters.

- For each cluster, the centre of gravity is calculated.

- Assignment of objects to clusters with the closest centre of gravity is changed.

- For each cluster, the new centre of gravity is calculated.

- The above stages are repeated until further reallocation of objects stops improving the general distances of the objects from the clusters' centres of gravity.

The quality of classification was assessed by a calculation of distances between the clusters. The division was done in order to maximise the distance between them.

\section{Registered unemployment in Poland in years 2008-2014}

The registered unemployment rate in Poland in years 2008-2014 was changing. In 2008 it was equal $9.5 \%$ and it rose to $13.4 \%$ during subsequent years (2012). It continued on this level in the year 2013 and fell to $11.4 \%$ in 2014. Similar changes could be observed in case of the number of registered unemployed persons (Figure 1). 
Numerous researches indicate that the unemployment in Poland is highly diversified spatially (Murawska, 2016; Tatarczak \& Boichuk, 2018; Woźniak-Jęchorek, 2015). It may result from the fact that the Polish labour market is highly disrupted by yearly fluctuations of other macroeconomic indicators (Hadas-Dyduch et al, 2016). The registered unemployment rate was different with respect to the voivodeship (Table 1). In the analysed period, the highest unemployment rate was in Warmińsko-Mazurskie voivodeship and the lowest - in Wielkopolskie. In the second case, there was an exception in 2009 - that year the lowest registered unemployment rate was in Mazowieckie voivodeship. It is obvious that the number of unemployed persons depends on the number of inhabitants of the analysed voivodeship. The highest number of registered unemployed persons was in Mazowieckie voivodeship and the lowest - in Opolskie.

The amounts of funds for the implementation of programmes for the promotion of employment, mitigating the effects of unemployment and professional activisation and other optional tasks in the voivodeship are determined by the minister in charge of labour, and at the level of poviats - by the voivodeship board according to the criteria defined by the voivodeship council.

The amount of expenditures for the implementation of programmes for the promotion of employment in Poland in years 2008-2014 was nuanced. Figure 2 presents the amount of this expenditures in fixed prices from 2014. In the years 2008-2014 the expenditures rose quickly. This increase was justified by the economic recession, which resulted in limited demand for work. The unemployed persons had then definitely less chances for finding a job on the labour market. In the year 2011, with respect to previous year, these expenditures decreased abruptly (by about 64\%). It was connected with the necessity of reducing public finance spending. Indeed, Poland was the subject to an excessive deficit procedure and, in line with the Ecofin Council recommendation (of July $7^{\text {th }} 2009$ ), was required to correct the general government deficit below 3\% of GDP by 2012. Being the subject to this procedure was connected with reduction of expenditures of the Labour Fund, which is included in this sector. Next, in years 2010-2014 the expenditures begun to grow again. Their amounts were nuanced in particular voivodeships. It was the highest in Mazowieckie voivodeship and the lowest — in Opolskie voivodeship (Figure 3).

The research was conducted on the basis of statistical data referring to the cost and employment effectiveness. They are published in the elaborations of the Ministry of Family, Labour and Social Policy (2009-2014). The cost and employment effectiveness are calculated for basic forms of professional activisation. The catalogue of these forms is determined by the 
minister in charge of labour. During the period 2008-2014 this catalogue was changing. Because of the auxiliary character or insignificant share in incurred nationwide expenditures, in 2008-2014 some forms of support were not considered in the catalogue of basic forms of professional activisation (for example activisation allowance, scholarships in the period of continuing education, reimbursement of travel and accommodation costs, reimbursement of social security contributions to farmers made redundant from work, training loans).

Table 2 presents the number of the unemployed persons participating, graduating and employed after completion of participation in activisation programmes. In the first three years of the analysed period this number was increasing and much higher than in the subsequent years.

Table 3 presents the structure of the unemployed persons participating in the basic forms of professional activisation. The largest number of persons participated in internships and trainings. The least number of people were activised by retrofitting or equipping workstations. In Table 3 the fields with missing data refer to the forms of professional activisation which in subsequent years stopped being counted as basic.

In the years 2008-2010 the high increase of the cost effectiveness (from about 9.1 thous. to about 13 thous. PLN) was accompanied by relatively constant employment effectiveness on the level of about 55\% (Figure 4). In the year 2011, with respect to the previous year, the cost effectiveness decreased from about 13 thous. PLN to about 9 thous. PLN. Next, both forms of effectiveness showed increasing trends. It indicates the better use of funds for professional activisation of the unemployed persons in the years 2011-2014.

\section{Results of poviats clustering}

As a result of clustering, in the years 2008, 2009, 2012 and 2014 three clusters of poviats with respect to the cost and employment effectiveness were selected. In the year 2013 four clusters were selected, and in 2010 and 2011 -5 .

In every year cluster 1 contained poviats with the best (the highest) values of the employment effectiveness and the best (the lowest) values of the cost effectiveness. The cluster with the highest number always had poviats with the worst values of these features.

The clustering of poviats, showed an interesting tendency. In the years 2008 clustering 2011 poviats with the highest values of employment effectiveness, had them on a relatively stable level between $57.5 \%-61 \%$ (Table 
4). At the same time, the values of this feature amongst poviats with the most disadvantageous values of the employment effectiveness were even less diversified (between $43 \%$ and $45.44 \%$ ). In this case, the trend was declining. The years 2012-2014 were characterised by a clear upward trend of the mean employment effectiveness in both the first, the best, cluster (from $65 \%$ to over $81 \%$ ) and in the last, the worst, one (from $58 \%$ to $72 \%$ ). It can also be observed that since 2013 poviats with the worst values of the employment effectiveness had them on the level not worse than the best poviats in the years 2008-2011. Such a trend cannot be observed in the case of the cost effectiveness. On average, the most advantageous values of the cost effectiveness were in the year 2008 (in all clusters), and the most disadvantageous - in 2010. Generally, it can be said that over time the effectiveness of basic forms of professional activisation was increasing it is visible in increasing values of then employment effectiveness that at the end of the analysed period have increased significantly since the beginning.

The relationship between the values of employment and cost effectiveness and the registered unemployment rate was analysed by means of the Spearman's rank correlation coefficient. It is expected that the relationship between the employment effectiveness and the unemployment rate should be negative (the higher the effectiveness, the lower unemployment), while the relationship between the cost effectiveness and the unemployment rate should be positive. The relationship between both types of effectiveness and the unemployment rate for the whole country was generally statistically significant but the correlation strength was small (Table 5). For the first cluster in the years 2009 and 2010 the relationship was significant, but weak for both types of effectiveness. In the years 2013 and 2014 it was significant only for the employment effectiveness. In the case of classes with the most disadvantageous values of both types of effectiveness, in the year 2010 the correlation between them and the registered unemployment rate was the strongest and statistically significant. In the years 2008, 2012 and 2013 the correlations between the employment effectiveness and the registered unemployment rate were significant. To sum up, we can state that no type of the effectiveness was the determinant of the registered unemployment rate (Table 5, Figure 5, Figure 6, Figure 7). Even in case of significant relationship the correlation strength was so weak that we cannot say about the influence of applied forms of professional activisation on the change of the registered unemployment rate. 


\section{Discussion}

The performed analysis shows that in the poviats of the middle-east Poland the values of effectiveness of forms of professional activisation belonged to worse groups. In these poviats the unemployment rate, in turn, was not among the highest in Poland. In the northern poviats of Warmia and Mazury, the registered unemployment rate was high, and the cost and employment effectiveness had disadvantageous values. Similar results were obtained for several poviats of Świętokrzyskie voivodeship. In poviats of north-western and western Poland the registered unemployment rate was among the highest and at the same time the funds for activisation of the unemployed were well used. In some poviats of the Pomorskie and Wielkopolskie voivodeship with the low registered unemployment rate the effectiveness of the activisation programmes was high. From the point of view of the social policy, the most undesirable situation is when for the high unemployment rate the use of funds for activation of the unemployed persons is poor. In such a case, the modification of activities of the labour offices should be considered in order to better adjust their activities to the specificity of the areas concerned and the needs of the labour market. On the other hand, if the effectiveness of the measures is high and the unemployment rate remains high, it might be worth considering reaching more registered unemployed people with the programmes.

\section{Conclusions}

In the article the clustering of poviats in Poland into homogeneous clusters with respect to the effectiveness of basic forms of professional activisation in the years 2008-2014 was done. The conducted analysis did not allow to state unambiguously which parts of Poland were characterised by better use of funds for activisation of the unemployed persons. It is probably caused by the fact that the research pertained to small territorial units - poviats. Part of them has such a small number of people covered by the programmes that it is virtually impossible to notice any regularity.

Despite the difficulties of the analysis at the poviat level, assessment of effectiveness of the forms of professional activisation on this level is fully justified. It is the poviat labour offices that receive appropriate funds and lead the activisation programmes and it is their actions that determine to a large extent the effective counteraction of unemployment. However, it is worth noting that all bodies of research done on the poviat levels will always be burdened with high level of uncertainty. Many poviats are small 
ones, with small number of inhabitants, hence the small number of persons on whom the activisation programmes are focused. This is the most important limitation of such analyses.

Future area of research will include the analysis of effectiveness of labour market policy in other European countries, with particular consideration of the Visegrad Group countries. Consideration of these countries together is justified because of their simultaneous political transformation. It was caused by similar political reasons and generated similar economic changes.

\section{References}

Adil, I. H., \& Irshad, A. R. (2015). A modified approach for detection of outliers. Pakistan Journal of Statistics and Operation Research, XI(1). doi: 10.18187/pjsor.v11i1.500.

Bieszk-Stolorz, B. (2017). Cumulative incidence function in studies on the duration of the unemployment exit process. Folia Oeconomica Stetinensia, 1. doi:10.1515/foli-2017-0011.

Bieszk-Stolorz, B., \& Markowicz I. (2015). Application of survival analysis in efficiency evaluation of professional effectiveness enhancement programme. Acta Universitatis Lodziensis. Folia Oeconomica, 1(311). doi: 10.18778/02086018.311.09.

Calmfors, L., Forslund, A., \& Hemstrom, M. (2002). Does active labour market policy work? Lessons from the Swedish experiences. CESifo Working Paper Series, 675 .

Card, D. E., \& Levine, P. B. (2000). Extended benefits and the duration of UI spells: evidence from the New Jersey extended benefit program. Journal of Public Economics, 78(1). doi: 10.1016/S0047-2727(99)00113-9.

Charrad, M., Ghazzali, N., Boiteau, V., \& Niknafs, A. (2014). NbClust package for determining the number of clusters in a dataset. In Conference paper: 5 th meeting on statistics and data mining at: Djerba. Tunisia.

European Commission (2013). Design and commissioning of counterfactual impact evaluations, Luxembourg: Publications Office of the European Union. Retrieved from: https://taipi.eu/object/document/20/attach/KE-30-13-216ENN.pdf (23.10.2018).

Gerfin, M., \& Lechner, M. (2002). A microeconometric evaluation of the active labour market policy in Switzerland. Economic Journal, 112(482). doi: 10.1111/1468-0297.00072. 
Hadas-Dyduch, M., Pietrzak, M. B., \& Balcerzak A. P. (2016). Wavelet analysis of unemployment rate in Visegrad countries. In T. Kliestik (Ed.). 16th international scientific conference globalization and its socio-economic consequences. University of Zilina, The Faculty of Operation and Economics of Transport and Communication, Department of Economics, 5th - 6th October 2016. (Part II.). Zilina: University of Zilina.

Hahn, J., Todd, P., \& Van der Klaauw W. (2001). Identification and estimation of treatment effects with a regression-discontinuity design. Econometrica, 69(1). doi: 10.1111/1468-0262.00183.

Heckman, J. J., Lalonde, R. J., \& Smith, J. A. (1999). The economics and econometrics of active labor market programs. In Handbook of labor economics, 3 PART(1). doi: 10.1016/S1573-4463(99)03012-6.

Hunt, J. (1995). The effect of unemployment compensation on unemployment duration in Germany. Journal of Labor Economics, 13(1). doi: $10.1086 / 298369$.

Jacobi, L., \& Kluve, J. (2006). Before and after the Hartz reforms: the performance of active labour market policy in Germany. IZA Discussion Paper, 2100.

Katz, L., \& Meyer, B. (1990). The impact of the potential duration of unemployment benefits on the duration of unemployment. Journal of Public Economics, 41(1). doi: 10.1016/0047-2727(92)90056-L.

Knapińska, M., \& Małecka-Ziembińska, E. (2016). Productivity and labor costs in the OECD countries - elements of comparing analysis. Business and Management Review, 7(3).

Lalive, R. (2007). Unemployment benefits, unemployment duration, and postunemployment jobs: a regression discontinuity approach. American Economic Review, 97(2). doi: 10.1257/aer.97.2.108.

Local Data Bank. Retrieved from: https://bdl.stat.gov.pl/BDL/start (25.10.2018).

Moffitt, R. A. (1985). Unemployment insurance and distribution of unemployment spells. Journal of Econometrics, 28(1). doi: 10.1016/0304-4076(85)90068-5.

MRPiPS. Retrieved from https://archiwum.mpips.gov.pl/praca/fundusz-pracy/efek tywnosc-form-promocji-zatrudnienia-i-aktywizacji-zawodowej/ (15.09.2018).

Murawska, A. (2016). Differences in unemployment among persons in a special situation on the labour market on the example of Polish provinces. Oeconomia Copernicana, 7(3). doi: 10.12775/OeC.2016.022.

Reddy, D., \& Jana, P. K. (2012). Initialization for K-means clustering using Voronoi diagram. Procedia Technology, 4. doi: 10.1016/j.protcy.2012.05.061.

Tatarczak, A., \& Boichuk, O. (2018). The multivariate techniques in evaluation of unemployment analysis of Polish regions. Oeconomia Copernicana, 9(3). doi: 10.24136/oc.2018.018.

Wiśniewski, Z., \& Maksim, M. (2013). Active labour market policies in Poland. CESifo Forum, 14(1).

Woźniak-Jęchorek, B. (2015). Institutional determinants of regional diversity of labor market in Poland. Equilibrium. Quarterly Journal of Economics and Economic Policy, 10(1). doi: 10.1 2775/EQUIL.2015.007. 


\section{Annex}

Table 1. The registered unemployment rate in Poland in years 2008-2014 in voivodeships (\%)

\begin{tabular}{lccccccc}
\hline Voivodeship & $\mathbf{2 0 0 8}$ & $\mathbf{2 0 0 9}$ & $\mathbf{2 0 1 0}$ & $\mathbf{2 0 1 1}$ & $\mathbf{2 0 1 2}$ & $\mathbf{2 0 1 3}$ & $\mathbf{2 0 1 4}$ \\
\hline Dolnośląskie & 10.0 & 12.8 & 13.1 & 12.4 & 13.5 & 13.1 & 10.4 \\
Kujawsko-pomorskie & 13.3 & 16.2 & 17.0 & 17.0 & 18.1 & 18.2 & 15.5 \\
Lubelskie & 11.2 & 12.9 & 13.1 & 13.2 & 14.2 & 14.4 & 12.6 \\
Lubuskie & 12.5 & 16.2 & 15.5 & 15.4 & 15.9 & 15.7 & 12.5 \\
Łódzkie & 9.2 & 11.9 & 12.2 & 12.9 & 14.0 & 14.1 & 11.8 \\
Małopolskie & 7.5 & 9.7 & 10.4 & 10.5 & 11.4 & 11.5 & 9.7 \\
Mazowieckie & 7.3 & 9.0 & 9.7 & 9.8 & 10.7 & 11.1 & 9.6 \\
Opolskie & 9.8 & 12.9 & 13.6 & 13.3 & 14.4 & 14.2 & 11.8 \\
Podkarpackie & 13.0 & 15.9 & 15.4 & 15.5 & 16.4 & 16.3 & 14.6 \\
Podlaskie & 9.7 & 12.8 & 13.8 & 14.1 & 14.7 & 15.1 & 12.9 \\
Pomorskie & 8.4 & 11.9 & 12.3 & 12.5 & 13.4 & 13.2 & 11.1 \\
Śląskie & 6.9 & 9.4 & 10.0 & 10.2 & 11.1 & 11.3 & 9.6 \\
Şwiętokrzyskie & 13.7 & 15.1 & 15.2 & 15.2 & 16.0 & 16.6 & 14.1 \\
Warmińsko-mazurskie & 16.8 & 20.7 & 20.0 & 20.2 & 21.3 & 21.6 & 18.7 \\
Wielkopolskie & 6.4 & 9.2 & 9.2 & 9.1 & 9.8 & 9.6 & 7.6 \\
Zachodniopomorskie & 13.3 & 17.1 & 17.8 & 17.6 & 18.2 & 18.0 & 15.5 \\
\hline
\end{tabular}

Source: own elaboration on the basis of the Local Data Base.

Table 2. The number of the unemployed persons participating, graduating and employed after completion of participation in the activisation programmes in years 2008-2014

\begin{tabular}{cccc}
\hline & \multicolumn{3}{c}{ Number of the unemployed persons } \\
\cline { 2 - 4 } Year & $\begin{array}{c}\text { participating } \\
\text { in the programmes }\end{array}$ & $\begin{array}{c}\text { graduating } \\
\text { from the programmes }\end{array}$ & $\begin{array}{c}\text { employed after completion } \\
\text { of participation in the activisation } \\
\text { programmes }\end{array}$ \\
\hline 2008 & 652,314 & 607,361 & 340,064 \\
2009 & 684,624 & 651,245 & 346,485 \\
2010 & 788,674 & 759,262 & 411,153 \\
2011 & 302,002 & 382,266 & 212,854 \\
2012 & 428,298 & 378,534 & 230,426 \\
2013 & 460,773 & 458,250 & 290,310 \\
2014 & 442,187 & 412,506 & 314,542 \\
\hline
\end{tabular}


Table 3. The structure of the unemployed people beginning participation in basic forms of activisation in Poland in the years 2008-2014

\begin{tabular}{|c|c|c|c|c|c|c|c|c|}
\hline \multirow[b]{2}{*}{ Year } & \multicolumn{8}{|c|}{ Basic forms of professional activisation } \\
\hline & 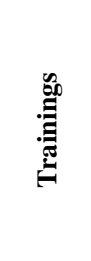 & 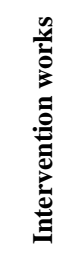 & 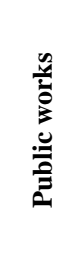 & 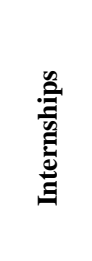 & 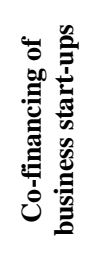 & 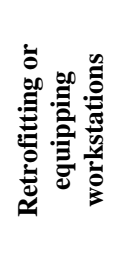 & 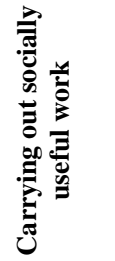 & 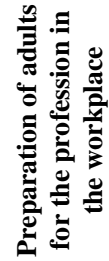 \\
\hline 2008 & $25.8 \%$ & $7.1 \%$ & $6.8 \%$ & $26.0 \%$ & $8.0 \%$ & $4.3 \%$ & $9.8 \%$ & $12.2 \%$ \\
\hline 2009 & $24.6 \%$ & $5.9 \%$ & $7.9 \%$ & $37.5 \%$ & $9.3 \%$ & $4.1 \%$ & $9.6 \%$ & $1.1 \%$ \\
\hline 2010 & $23.1 \%$ & $5.5 \%$ & $9.5 \%$ & $38.0 \%$ & $9.8 \%$ & $5.5 \%$ & $8.6 \%$ & - \\
\hline 2011 & $17.8 \%$ & $9.4 \%$ & $7.6 \%$ & $36.6 \%$ & $8.6 \%$ & $3.5 \%$ & $16.5 \%$ & - \\
\hline 2012 & $18.8 \%$ & $7.4 \%$ & $7.1 \%$ & $41.3 \%$ & $9.2 \%$ & $5.2 \%$ & $11.0 \%$ & - \\
\hline 2013 & $18.4 \%$ & $7.4 \%$ & $7.1 \%$ & $42.1 \%$ & $9.8 \%$ & $5.1 \%$ & $10.1 \%$ & - \\
\hline 2014 & $17.8 \%$ & $7.0 \%$ & $7.4 \%$ & $49.7 \%$ & $11.3 \%$ & $6.8 \%$ & - & - \\
\hline
\end{tabular}

Table 4. Mean employment and cost effectiveness in particular clusters in the years 2008-2014

\begin{tabular}{|c|c|c|c|c|c|c|}
\hline \multirow{2}{*}{ Year } & \multirow{2}{*}{ Effectiveness } & \multicolumn{5}{|c|}{ Cluster } \\
\hline & & 1 & 2 & 3 & 4 & 5 \\
\hline \multirow{2}{*}{2008} & employment & $61.09 \%$ & $52.13 \%$ & $45.44 \%$ & - & - \\
\hline & cost & $8,557.95 \mathrm{zł}$ & $11,075.91 \mathrm{zf}$ & $12,826.53 \mathrm{zt}$ & - & - \\
\hline \multirow{2}{*}{2009} & employment & $57.46 \%$ & $50.08 \%$ & $44.44 \%$ & - & - \\
\hline & cost & $11,014.50 \mathrm{zł}$ & $13,385.78 \mathrm{zł}$ & $15,685.24 \mathrm{zł}$ & - & - \\
\hline \multirow{2}{*}{2010} & employment & $59.45 \%$ & $57.65 \%$ & $53.60 \%$ & $48.79 \%$ & $43.90 \%$ \\
\hline & cost & $11,675.02 \mathrm{zł}$ & $12,734.02 \mathrm{zł}$ & $14,093.35 \mathrm{zl}$ & $15,778.54 \mathrm{zl}$ & $18,414.47 \mathrm{zl}$ \\
\hline \multirow{2}{*}{2011} & employment & $60.46 \%$ & $60.19 \%$ & $56.74 \%$ & $50.08 \%$ & $43.09 \%$ \\
\hline & cost & $8,178.43 \mathrm{zf}$ & $8,710.19 \mathrm{zl}$ & $9,890.02 \mathrm{zf}$ & $11,448.04 \mathrm{zł}$ & $13,595.93 \mathrm{zł}$ \\
\hline \multirow{2}{*}{2012} & employment & $65.05 \%$ & $60.88 \%$ & $58.34 \%$ & - & - \\
\hline & cost & $9,949.35 \mathrm{zł}$ & $12,052.14 \mathrm{zl}$ & $12,694.78 \mathrm{zl}$ & - & - \\
\hline \multirow{2}{*}{2013} & employment & $67.68 \%$ & $64.76 \%$ & $64.96 \%$ & $60.26 \%$ & - \\
\hline & cost & $9,967.50 \mathrm{zł}$ & $11,288.75 \mathrm{zl}$ & $11,804.52 \mathrm{zl}$ & $13,113.16 \mathrm{zł}$ & - \\
\hline \multirow{2}{*}{2014} & employment & $81.57 \%$ & $76.28 \%$ & $72.01 \%$ & - & - \\
\hline & cost & $10,219.30 \mathrm{zł}$ & $11,611.62 \mathrm{zt}$ & $12,778.24 \mathrm{zl}$ & - & - \\
\hline
\end{tabular}


Table 5. Spearman's rank correlation coefficients between the cost and employment effectiveness and the registered unemployment rate in the years 20082014

\begin{tabular}{lcrrrrrr}
\hline \multirow{2}{*}{ Year } & \multirow{2}{*}{ Effectiveness } & \multirow{2}{*}{ Total } & \multicolumn{7}{c}{ Cluster } \\
\cline { 5 - 8 } & & & $\mathbf{1}$ & $\mathbf{2}$ & \multicolumn{1}{c}{$\mathbf{3}$} & $\mathbf{4}$ & $\mathbf{5}$ \\
\hline \multirow{2}{*}{2008} & employment & $\mathbf{- 0 . 1 4 2 9}$ & -0.0346 & -0.1378 & $\mathbf{- 0 . 3 0 5 1}$ & - & - \\
& cost & $\mathbf{0 . 1 6 4 8}$ & 0.0920 & $\mathbf{0 . 2 0 6 6}$ & 0.1501 & - & - \\
\hline \multirow{2}{*}{2009} & employment & -0.0259 & $\mathbf{- 0 . 2 4 6 0}$ & -0.0707 & 0.0734 & - & - \\
& cost & $\mathbf{0 . 1 2 7 4}$ & $\mathbf{0 . 3 3 6 4}$ & 0.0978 & 0.0691 & - & - \\
\hline \multirow{2}{*}{2010} & employment & $\mathbf{- 0 . 1 3 3 6}$ & $\mathbf{- 0 . 2 8 6 3}$ & 0.0439 & -0.0422 & -0.2125 & $\mathbf{- 0 . 3 5 8 5}$ \\
& cost & $\mathbf{0 . 1 7 1 5}$ & $\mathbf{0 . 2 3 7 0}$ & 0.0591 & $\mathbf{0 . 2 5 7 5}$ & 0.1589 & $\mathbf{0 . 3 3 3 7}$ \\
\hline \multirow{2}{*}{2011} & employment & $\mathbf{- 0 . 1 9 2 3}$ & 0.0031 & -0.1033 & -0.1966 & -0.2338 & -0.0010 \\
& cost & $\mathbf{0 . 1 8 1 5}$ & -0.0120 & $\mathbf{0 . 2 0 6 1}$ & $\mathbf{0 . 3 1 8 8}$ & $\mathbf{- 0 . 3 1 5 5}$ & 0.0315 \\
\hline \multirow{2}{*}{2012} & employment & -0.0738 & -0.0279 & 0.0238 & $\mathbf{- 0 . 2 5 0 6}$ & - & - \\
& cost & 0.0972 & 0.0762 & 0.1368 & 0.1842 & - & - \\
\hline \multirow{2}{*}{2013} & employment & $\mathbf{- 0 . 2 0 0 1}$ & $\mathbf{- 0 . 3 7 3 7}$ & -0.0847 & 0.0000 & $\mathbf{- 0 . 3 6 6 0}$ & - \\
& cost & 0.0563 & 0.0208 & -0.0182 & 0.0844 & 0.0769 & - \\
\hline \multirow{2}{*}{2014} & employment & $\mathbf{- 0 . 1 5 8 5}$ & $\mathbf{- 0 . 1 8 8 0}$ & $\mathbf{- 0 . 2 0 5 9}$ & -0.0025 & - & - \\
& cost & $\mathbf{0 . 1 0 8 8}$ & -0.0332 & $\mathbf{0 . 2 9 2 9}$ & 0.0385 & - & - \\
\hline
\end{tabular}

Figure 1. Registered unemployment rate and the number of registered unemployed persons in Poland in years 2008-2014

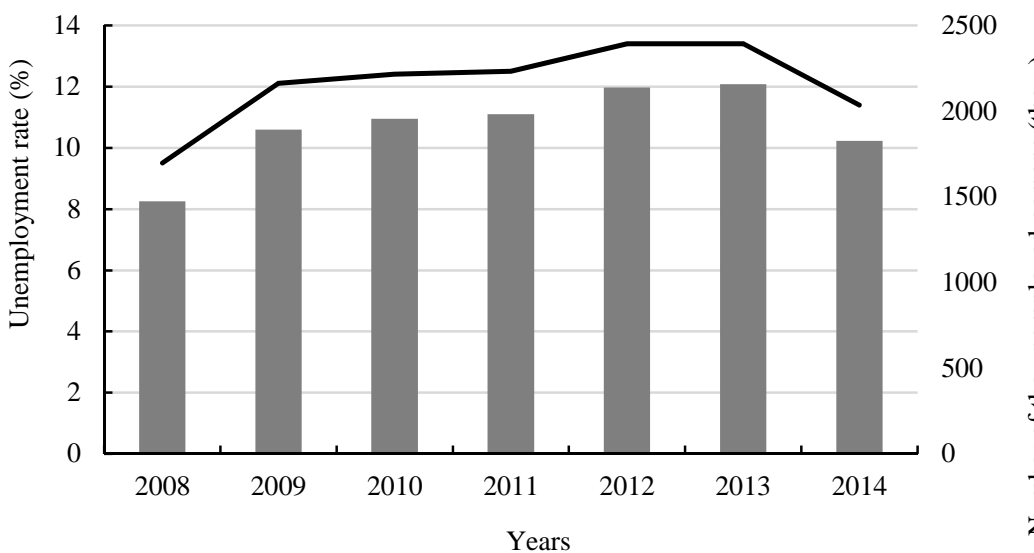

Number of the unemployed persons —Unemployment rate

Source: own elaboration on the basis of the Local Data Base. 
Figure 2. Expenditures for the implementation of programmes of professional activisation in Poland in years 2008-2014 (mm PLN, fixed prices from 2014)

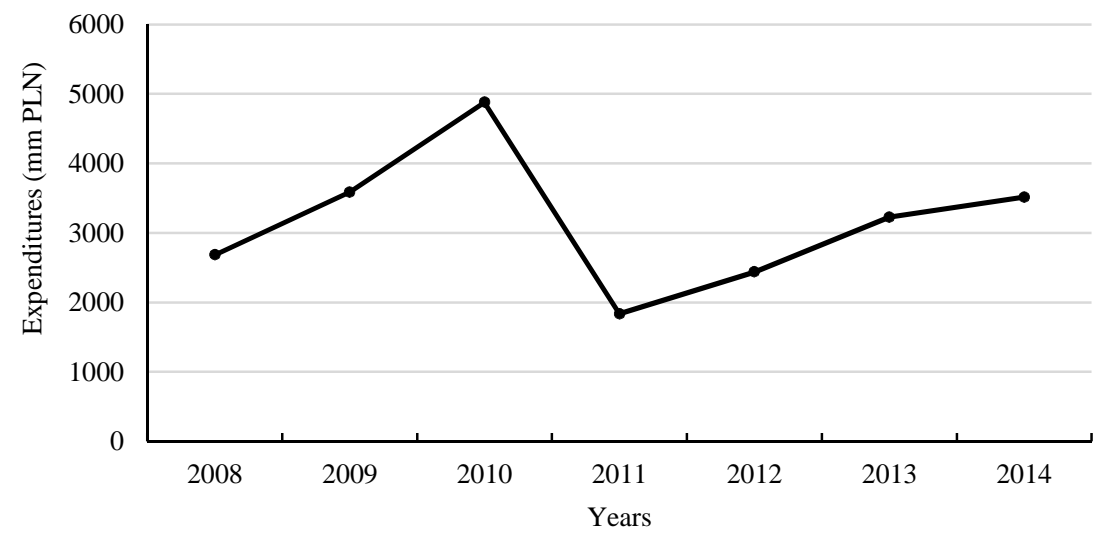

Figure 3. Structure of expenditures for implementation of programmes of professional activisation in 2014 with respect to voivodeships (\%)

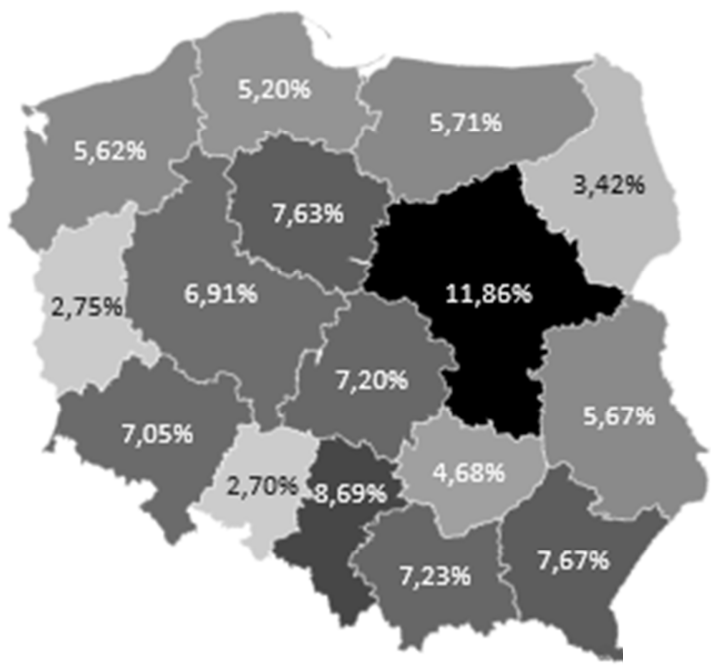


Figure 4. Total cost and employment effectiveness of activation programmes in Poland in 2008-2014

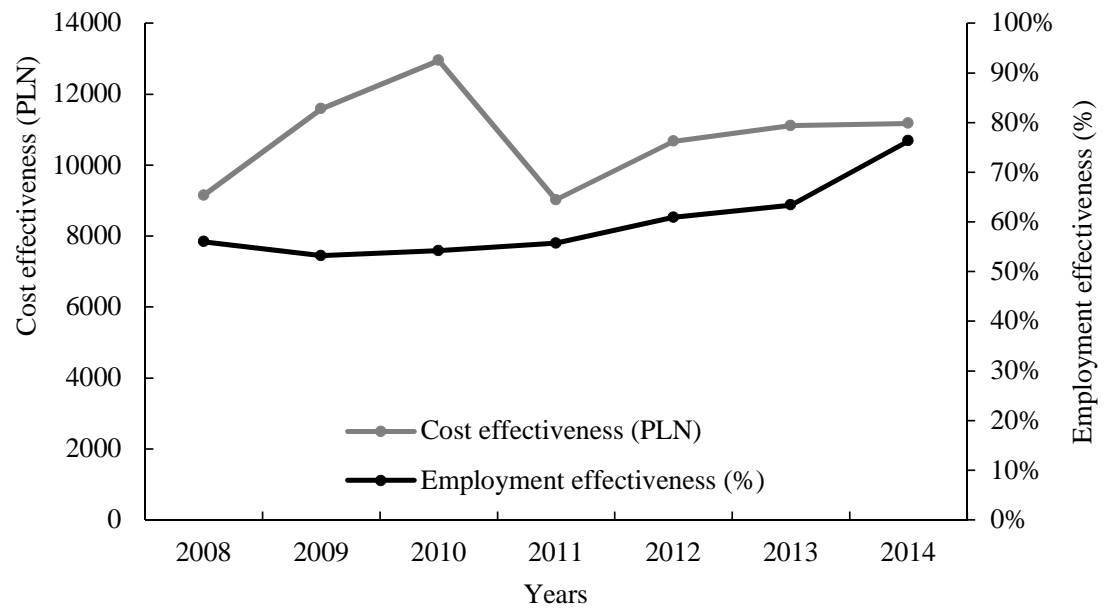

